\title{
Human-machine tool shop management system
}

\author{
Kalandarov Ilyos Ibodullayevich \\ Nukus branch of Navoi State Mining Institute, Nukus, 230103, Uzbekistan
}

\begin{abstract}
The article describes a human-machine tool shop management system based on the developed models and algorithms of production division management tasks. The calculation of the economic efficiency of the developed management system is carried out. The developed online management system increases the economic efficiency of managing a modern production unit. This management system, as shown by its operation, has the ability to form management decisions, making extensive use of the ability of operational shop staff to navigate in informal situations due to their experience, intuition, and forecasting the development of the production situation. With this approach to the management process, it is possible to involve hidden reserves and other resources in the production sphere on the basis of the development of creative initiative of the heads of production units and site management personnel. In addition, having the ability to quickly respond to changes in the production environment, the dialog control system allows you to more effectively than with batch information processing systems to stabilize the course of the production process when it is affected by various random factors. The ability to synchronize in real time the interaction of all workplaces (WP) of production sites is implemented, thereby significantly reducing the duration of production cycles for manufacturing products, work in progress, improving the rhythm of production, increasing labor productivity.
\end{abstract}

Keywords: workplaces, human-machine system, tool shop, production units, informal situation, production area, production cycle.

\section{Introduction}

Software management system. The developed production division management system is an instrumental multi-user real-time system for the shop management level [1]. The system is designed to manage the organization of production, control, accounting and operational management of manufacturing processes of technological equipment in the tool shop.

Hardware and software management system present the users the opportunity to obtain real-time information about the status and progress of production processes thereby increase efficiency of decision-making, providing performance targets for the volume and range of manufactured product.

The control system consists of two subsystems:

Operational management;

- Management of production organization.

The software of the subsystem of operational management solves questions of operational architecture, operational accounting and control of the production process, operational control of the production process in the tool shop and consists of the following tasks:

1)Formation and maintenance of an information base;

2)Operational planning;

3)Accounting and control of the production process;

4)Regulation of the production process;

5)Reporting.

The main function performed by the production management subsystem is to prepare the organizational structure of the production areas of the shop for the successful solution of the task of calendar planning and balancing the monthly production program with the production capacity available for this planned period of time. The subsystem includes one set of tasks: operational management of production organization [2].

A block diagram of the automated tool shop management system is shown in Fig.1. 


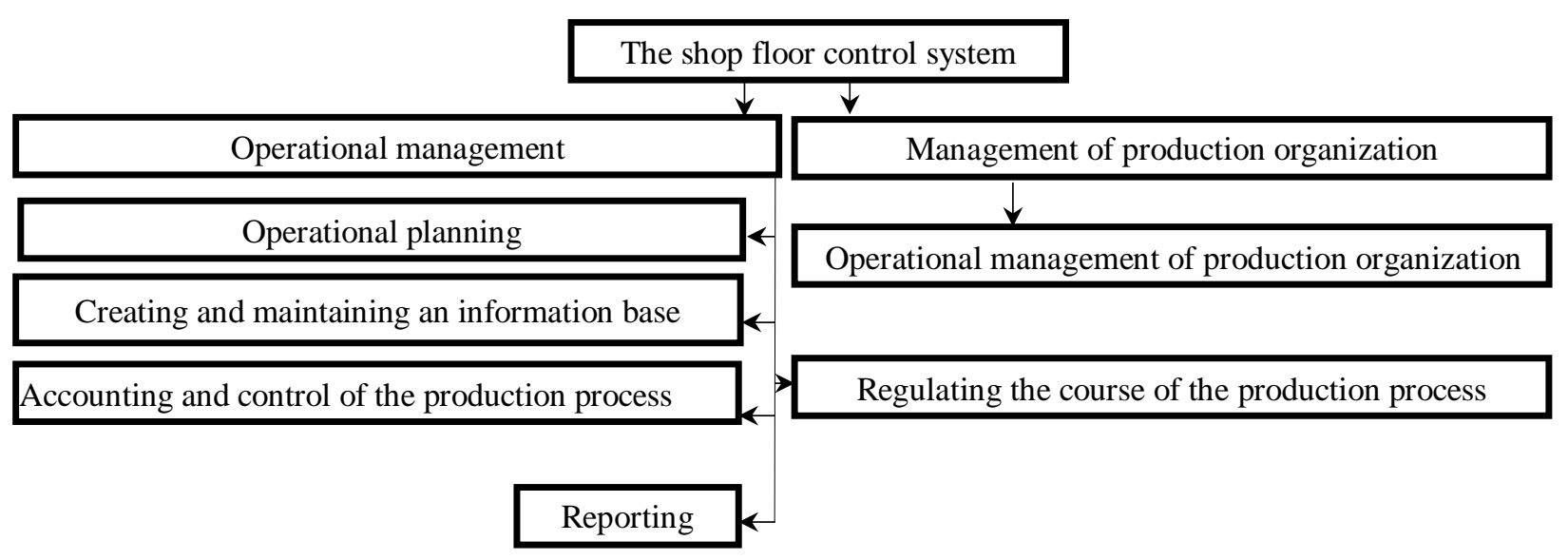

Fig.1. Block diagram of tool shop management systems

The Operational planning task Suite consists of the following tasks:

- $\quad$ Operational shift planning;

- $\quad$ Simulation of the site operation for a week;

- $\quad$ Formation of a weekly plan according to orders;

- $\quad$ Calculation of routes of parts by working places of the site;

- $\quad$ The formation of the belt loading equipment.

The task "operational shift planning" forms a shift task for each WP, taking into account the Fund of available time for WP, as well as the issuance of enlarged shift tasks for blacksmithing, heat treatment, coatings and welding.

In the task «Simulation modeling of the work of the site for a week», the work of the production site during the week is modeled in order to quickly regulate the course of the production process [3].

Task "Order regulation" allows you to influence the progress of the production process by changing the order priority. At the same time, changing the order priority means changing the production process of all parts of the order (i.e. speeding up its completion or Vice versa).

The solution of the problem "Post-operative regulation" allows you to influence the progress of the production process by changing the priority of operations. In this case, changing the priority of operations means changing the production process of a particular order part.

As part of the task Suite "Reporting" tasks included:

- $\quad$ generating a report on the site's work on orders from the beginning of the month;

- $\quad$ generating a report on site operation by groups of process equipment per shift.

This set of tasks generates information about the completed volumes of work for sections with an incremental total from the beginning of the month and per shift.

Complex of tasks "Formation and maintenance of an information base" it consists of the following tasks [4]:

- $\quad$ Maintaining the order file of the accumulation array;

- $\quad$ Maintaining a file of route and technological maps of the accumulation array;

- $\quad$ Maintaining the monthly plan order file;

- $\quad$ Maintaining a file of route and technological maps of the monthly plan;

- $\quad$ Program interface for the accumulation array with a monthly plan;

- $\quad$ Maintaining normative and reference information.

In order to reduce the time for entering large amounts of source information, accumulation sites were created that allowed storing information as it arrived, and then rewriting it into working files (tasks "Managing the order soldering array accumulation", "Maintaining a file of route and process maps in the accumulation array", "Program interface for the accumulation array with a monthly plan") [5].

Creating and maintaining working files is performed by solving tasks "Maintaining the monthly plan order file" and "Maintaining a file of route and process maps for the monthly plan".

Software for the task Suite "Operational management of production organization" solves the issues of placing workers on the equipment of production sites, specialization of changing the production structure of 1 sites consists of the following tasks:

Forming aggregates;

- $\quad$ Organization of specialized work places on shift; 
Management of the production structure of the workshop [6].

The tool shop management system allows you to solve production process management issues in an online mode, with automation of control points, as well as issuing reference information necessary for making management decisions to operational shop personnel.

The following output documents are the result of solving tool shop management tasks:

a) a set of tasks "Operational planning";

- $\quad$ Shift assignment-work order;

- $\quad$ Tape schedule of loading jobs on the site per shift;

- Information about the route of details to the working places of the site;

b) a set of tasks "Accounting and control of the production process";

- Weekly plan - report on orders;

- $\quad$ Monthly plan-report to the site;

- $\quad$ Monthly plan - report on orders;

C) a set of tasks "Reporting":

- $\quad$ Report on the work of the site;

- $\quad$ Certificate of the production process under the order;

d) a set of tasks "Formation and maintenance of an information base":

- $\quad$ Route and technological map on request;

- $\quad$ An array of savings, routing-routing-order;

- $\quad$ Reference list of process equipment sections and groups;

- Certificate of equipment and qualifications;

d) set of tasks "Operational management of production organization";

- $\quad$ Reference on labor intensity by groups of process equipment for orders of the site administration;

- $\quad$ Reference on the organization of working places on the site.

The management system software also includes service programs.

Service programs provide:

Protection of information from unauthorized access (user passwords);

Software control of input information;

The work of users, in accordance with the compiled "menu" [7].

\section{Materials and methods}

Description of the dialog in the management system. A distinctive feature of the process of solving problems of a human-machine nature is the dialog mode (online mode, online mode), in which the machine reacts to individual events of the real environment so quickly that it allows you to influence their course. In this case, events are registered using data entered from terminals; data related to a single event is processed until operations on them are fully or partially completed, regardless of other input messages [8].

The interaction of a human with a computer will be considered as a process of exchanging messages between a human and a computer, due to the need for sequential and (or) parallel execution of operations by a human and a machine to solve any task.

When interacting with the user, dialog systems usually provide [9]:

1) Direct contact between users and the system, i.e. receiving and issuing various messages via a local or remote terminal;

2) Immediate processing of received messages by the system, even if this processing is not fully performed, this function usually includes checking the syntactic correctness of the message, executing commands contained in the message, and displaying the results;

3) Search for user-required data (and / or programs), i.e., manage the library of programs and data);

4) The ability to serve multiple users almost simultaneously in an environment where the need for service is unpredictable.

\section{The operation of the control system}

To ensure the work of operational shop staff in real time, the shop has organized automated workplaces (AWP) of shop staff (AWP - shop Manager, AWP - dispatcher, AWP - technologist, AWP - master, AWP - operator) on the basis of remote terminals (see Fig.2).

For prompt input, processing of information and receipt of output documents, an information preparation group is 
organized in the shop.

Group training information (consisting of planning and control Bureau) shall collect baseline information (monthly plans, route-routing orders, exhaust replacement jobs at WP, the adjustment of the Fund's available time on the equipment), control over correctness of filling, entering information into Electronic computer, receiving the output documents and their issuance to users. The organization of this group allows you to centralize the process of processing large amounts of information, which makes it easier to control the information and increases the reliability of the entered information. The information preparation group consists of an engineer and two operators who have completed a computer training course before starting the pilot operation of the system.

Let's consider the work of subsystems and task complexes of the control system, taking into account the AWP-users on which they are solved [10].

\section{AWP Manager.}

After calculating the priorities of orders and forming the basic information on machine carriers by the information preparation group (monthly site plan, route and process maps for orders), the dispatcher works with a set of programs that implement the tasks of managing the organization of production.

Having received reference information on the volume of work of various complexity (the task of forming aggregates) and the reserve (or shortage) of workers with specific qualifications, the dispatcher solves the issue of placing workers at the expense of other sites (if there is a shortage) or transfers to other sites (if there is a reserve). The result of solving the problem is an organizational arrangement of workers behind the equipment of the sites, taking into account the complexity of the work. This concludes the first stage of balancing the production program and production capacity.

At the second stage (the task of managing the production structure of the shop), the dispatcher, based on information about the volume of work and the Fund of available time, solves the question of balancing the production program of the site for the planned period in two ways. The first way involves a lack of production capacity at the site, and the issue is resolved by including equipment from other sites, if they have a reserve of capacity. In this case, you can include a specific item in the section by making organizational adjustments (i.e. adjusting the hardware reference list) [11].

Performing the production organization management function allows you to "configure" the organizational structure of the plots for the production program.

The main condition for including an order in the production program is its security. a security mark for the order is set by the planning and dispatching (PD) dispatcher at the stage of forming the plan [12].

The input documents generated in the PD are:

- $\quad$ Statement of secured orders;

- $\quad$ Production program for the site in the planned period;

- $\quad$ Adjustment of the production program at the site in the planned period;

- $\quad$ Updating the reference list for equipment and available time.

A set of tasks is solved with the help of the AWP Manager "Operational management of production organization". AWP technologist.

The main task of the technological Bureau of the shop is to develop route and technological maps for orders. Based on this, this automated workplace is used to correct the array of route and process maps when changes occur in the technological process of making an order, and to correct the reference list for equipment and available time stock.

The input documents that are formed in the technology Bureau are:

route and technological maps for orders;

correcting route and process maps based on orders;

updating the reference list for equipment and available time.

For the functioning of the AWP -technologist, the tasks of the complex "Formation and maintenance of an information base" are used.

AWP masters.

The main purpose of this automated place is to enable the operational shop staff working on production sites to quickly regulate the course of the production process and receive all the initial information about the passage of orders in production in an online mode for making management decisions. Having complete information about the conclusion of work on orders and a schedule of work on the details of orders for each day, built by the task Simulation model of the site operation for a week» the wizard has the ability to quickly adjust the duration of product manufacturing cycles by changing the priorities of orders and operations. Increasing the order priority (operation priority) reduces the total production time of the product (part), while reducing it suspends or slows down its execution [13].

For qualitative tracking of the course of the production process, when accounting for completed works, the operation status code is set, which reflects not just the execution or non-execution of the technological operation, but also the state or possibility of its execution?

The operation status code can have the following values: 
$\mathbf{V}$ - Operation is performed;

A-the Operation was not started;

$\mathbf{N}$ - incomplete operation;

$\mathbf{N}$ is not the Operation of the coin to be performed.

Operation status codes play an important role in planning hardware loading. The operation status code means that when calculating the priority of operations, this operation will be assigned the highest priority for the purpose of mandatory priority loading of its equipment, and its labor intensity will be recalculated based on the number of processed parts. If the operation status code is $\mathrm{H}$, the process operation will not be scheduled for loading until it changes. Operation status codes allow the wizard to adjust the order in which parts are scheduled for processing, and not to start production of parts that cannot be processed for some reason [14].

Video grams "Information about the route details for working places on the site" and "Tape schedule of loading jobs on the site per shift" provide information about when and at which WP the order detail should be located, as well as how many equipment downtime and at what time, which allows the master to efficiently and quickly organize work on the RM and effectively solve the issue of reloading production capacity or redistributing work in case of equipment failure. Input documents generated at production sites are:

Completed shift assignments by work stations;

Directory of the Fund of available time and skills of workers by jobs;

Adjustment of the Fund of available time and qualification of workers by jobs;

List of changes in the priorities of orders;

List of changes to the operation priorities;

A list of changes to the operation status codes.

A set of tasks is used for the operation of the AWP wizard "Regulating the production process".

AWP - and head of production.

The organization of an automated workplace provides the shop management (shop managers, Deputy shop managers) with access to operational information about the course of the production process at the sites and by analyzing this information, the development of management decisions.

The automated workplace of the shop Manager uses a set of tasks "Accounting and control of the production process" and "Reporting".

AWP-operator of the information preparation group.

The solution of the main task of operational management-scheduling of loading for a shift-is carried out by the AWP operator. set of tasks "Operational planning" it is solved in automatic mode and gradually calculates the operation priorities, forming queues, and calculating shift tasks for the WP.

From this workplace, you can enter the main input documents that ensure the functioning of the tool shop management system:

Statement of supply orders;

Production program for the site in the planned period.

Adjustment of the program budget for the site in the planned period;

Route and technological maps for orders;

Completed shift assignments by work stations;

Directory of the Fund of available time and skills of workers by jobs;

Adjustment of the Fund of available time and qualification of workers for jobs.

The tasks of the complex are solved by the AWP operator "Reporting", which results in the following output documents:

Report on the site's work on orders from the beginning of the month;

A report on the work of the section for groups of technological equipment for a change.

\section{Conclusion}

The implementation of the calendar planning task allows you to calculate shift assignments for jobs based on a simple selection of work from the monthly plan, and taking into account the availability of orders and the performance of previous shift tasks. Creating and maintaining an order accumulation array improves the quality of the plan, since with a longer planning interval, there are more opportunities for optimization.

Implementation of production organization management tasks allows you to create a real production program. Forming a real monthly production program allows you to plan the work of supporting services in advance, which significantly increases the rhythm of production and the probability of fulfilling the monthly plan.

Using the dialog mode for generating control decisions makes it possible: 
production process;

take into account difficult to formalize factors and circumstances that characterize the state of the apply heuristic techniques and methods in the process of solving combinatorial problems of high dimensions (for example, tasks of calendar planning);

to find the results of solving multi-criteria problems that are effective from the point of view of a given user, which generally have a number of competing indicators.

\section{References}

\# Kabulov, A. V., Normatov, I. H., \& Kalandarov, I. I. (2013). Algorithmic model of management on the basis of algebra over functioning tables (FT). SCIENCE AND WORLD, 10.

\# Kabulov, A. V., Normatov, I. H., \& Kalandarov, I. I. (2015). ALGORITHMIC METHOD OF THE CONVERSION FUNCTIONING TABLES (FT) FOR CONTROL INDUSTRIAL SYSTEMS. Наука и Мир, 1(8), 14-17. Kalandarov, I. I. (2020). ALGORITHMS FOR SOLVING PROBLEMS OF MANAGING A PRODUCTION UNIT WITH A DISCRETE UNIT TYPE OF PRODUCTION. International Engineering Journal For Research \& Development, 5(4), 8-8. DOI:https://doi.org/10.17605/OSF.IO/3NR6X.

\# Kabulov, A. V., \& Normatov, I. H. (2015). Kalandarov II Algorithmic model of management on the basis of algebra over functioning tables (FT). Science and world» International scientific journal, (1), 10-13.

\# Кабулов, А. В., Норматов, И. Х., \& Каландаров, И. И. (2017). Алгоритмический подход управления сложными системами на примере производственных систем ДАН АН РУз, г. ДАН АН РУз., г. Ташкент, (1).

\# Kalandarov, I. I., Sotiboldiyev, S. U., \& Narzullayev, Y. E. (2019). Algorithm of the choice of the optimum technological route and the group equipment. Science and Education in Karakalpakstan ISSN 2181-9203, 27.

\#КАБУЛОВ, А., \& КАЛАНДАРОВ, И. (2018). ОПИСАНИЕ АРХИТЕКТУРЫ АЛГОРИТМИЧЕСКОЙ СИСТЕМЫ АТЛАС. In Инновационные геотехнологии при разработке рудных и нерудных месторождений (рp. 470-475).

\#Кабулов А.В., Норматов И.Х., Каландаров И.И. «Алгоритмическая модель управления на основе алгебры над таблицами функционирования», ISSN 2181-8460 «Проблемы вычислительной и прикладной математики». Центр разработки программных продуктов и аппаратно-программных комплексов (Ташкент) № 2 (4). 2016. с.19-24.

\# Kabulov, A. V., Normatov, I. H., \& Kalandarov, I. I. (2013). Algorithmic model of management on the basis of algebra over functioning tables (FT). SCIENCE AND WORLD, 10.

\# Каландаров, И. И., and С. Бекбутаев. "Algorithm for solving the optimal technological route tasks." (2019).

\# Каландаров И.И., Бобоев А.А., Меликулов $\quad$ С.Е., Тогаев С.Ф. Микропроцессорная система с распределенным управлением // В сборнике: Образовательная система: вопросы продуктивного взаимодействия наук в рамках технического прогресса сборник научных трудов. Казань, 2019. С. 357 359

\# Кабулов А.В., Каландаров И.И. Описание архитектуры алгоритмической системы АТЛАС // В сборнике: Инновационные геотехнологии при разработке рудных и нерудных месторождений Сборник докладов VII Международной научно-технической конференции в рамках Уральской горнопромышленной декады. Екатеринбург. 2018. С. 470-475.

\#Кабулов А.В., Норматов И.Х., Каландаров И.И. Алгоритмический модели управления сложными системами на основе таблиц функционирования // Сборник статей победителей Международной научнопрактическая конференция, состоявшейся 15 декабря 2016 г. в г. Пенза, С.66-68

\# Kabulov Anvar Vasilovich, Kalandarov Ilyos Ibodullayevich, Karimov Anvar Abduvoxidovich. (2020). Algorithmic And Mathematical Methods For Solving The Problem Of Calendar Planning Based On Dynamic Functioning Tables. International Journal of Advanced Science and Technology, 29(7), 9090-9097. Retrieved from http://sersc.org/journals/index.php/IJAST/article/view/26339

* Anvar Kabulov, Ilyos Kalandarov, Sherzod Boltaev. ISSN: 1943-023X Journal of Advanced Research in Dynamical and Control Systems - JARDCS Vol.12, Special Issue 6, (2020), pp.778-792, http://www.jardcs.org/abstract.php?id=5233 DOI: 10.5373/JARDCS/V12SP6/SP20201095 